\title{
INTRODUCCION
}

\section{Aldaba de Melilla: la historia interesada}

Vuelve ALDABA a recoger el guante que en permanente desafío lanzan los mil y un temas de la Historia de Melilla. En palabras de Robert Saladrigas, parece que la ciudad - y sus historiadores - requirieran peri6dicamente recomponer "las imágenes de su espejo". Nuestra propia historia parece comportarse como un espéculooráculo, de reflejos casi siempre sorprendentes.

A finales de 1987, salió el tercer número monográfico dedicado a la Historia de Melilla, que, además, festejaba el quinto aniversario de la revista. Dos años después emprendemos una nueva travesía, por rutas a veces desconocidas, a veces desacostumbradas. Es una navegación de cabotaje - tímida y sencilla, pero constante-que lleva siempre como puerto de referencia -en este portulano utópico de la historiaa la ciudad recostada en el piedemonte del Gurugú, ceñida por el brazo mineral de Tres Forcas, bañada en una escasa bahra de la Rusaddir eterna, alejada hacia la Playa de los Cárabos, la Laguna de Puerto Nuevo, Chafarinas y Cabo de Agua, ya cortada la arena por el hermoso estuario del Muluya —río de Moloch—, pisando la Mauritania Cesariense.

Una urbe como Mellilla, habitada "desde siempre" no puede agotar su mena histórica fácilmente. Otra cosa es diferenciar la ganga y dejar que fluya - como una cremallera de agua - el Río de Oro de nuestra historia. Las propias limitaciones humanas son manifiestas, aunque esta revista una vez más, es la constatación de una obra surgida de la colaboración y de la generosidad de muchas personas amantes de esta tierra sembrada de vientos cambiantes. Dejamos a la crítica positiva la ingrata labor de enjuiciar logros y aparear causalidades y casualidades.

Como el etólogo Konrad Lorenz, desaparecido este año, querrfamos confundir ética y estética, para ofrecer una revista bella e inteligente. No poseemos el don del ilustrado Riquete el del copete, pero queremos permanecer atentos a las transformaciones contínuas de esta ciudad. Una polis que a veces eleva su tensión y acelera el pulso historico, no debe sufrir las ausencias de investigadores apasionados, de artistas ilusionados, ni mucho menos de lectores avezados y ávidos. Esperemos que también comprensivos.

Hemos estructurado este cuarto número monográfico sobre la Historia de Melilla, en tres bloques diferenciados: Estudios; Monográfico; y, Reseñas Bibliográficas. Amén de ello, tenemos una importante aportación estética -y por tanto ética-en la cubierta y en la contracubierta, maquetas diseñadas por nuestro amigo Carlos Baeza. Las postales que "colorean" la cubierta están plenas de ingenuidad, podemos decir que es una visión naif de las Campañas de Marruecos. Baste con leer las leyendas que 
acompañas a las fotografías - de izquierda a derecha y de arriba abajo-:

Postal 1": "A mi madre le escribo que te quiero

y que a tu lado sigo...prisionero".

Postal 2: "Corazón de padre

No te sorprendas morita

que no vengo ha(sic) hacerte daño

yo también tengo en España

un bebé que tendrá un año".

Postal 3": "En las orillas del Kert

Déjame querida hermana

que me acerque a este cirstiano

porque no es tan inhumano

como padre lo pinto".

Postal 4\% "Entre dos Fuegos (Solapa de cubierta)

Examiné a mi paso, lo he hallado

una bala le hirio ipobre soldado!

Es una visión "dulce" de un conflicto que enfrentó a España con sus propios fantasmas colonialistas entre 1860 y 1927, en las tierras del norte de Marruecos, en un territorio prácticamente desconocido y tradicionalmente indómito - a semejanza del extinguido león del Atlas-balizado por ríos de agua y de sangre en las campanfas de 1909,1912 y1921, sin olvidar la llamada "Guerra de Margallo", acontecida en Melilla en 1893, a modo de guerra religiosa y marabútica, como las de la era moderna, que nos narra la leyenda del suceso del morabito, escrita en los sillares de Melilla la Vieja con cincel de adagas y bayonetas.

El primer bloque -Estudios- lo inicia una investigación sobre los albores de la Melilla española, a finales del siglo XV, en 1497, cuando como escribe el novelista libanés Amin Maalouf -por boca de León el Africano-: "Aquel año cayó Melilla en manos de castellanos. Había venido una flota para atacarla, la hallo desierta, abandonada por su habitantes que habían huído hacia las colinas próximas, llevándose sus bienes. Los cristianos se apoderaron de la ciudad y cmpezaron a fortificarla. ¡ Sabe Dios si la abandonarán algún día!

En Fez, los refugiados granadinos se asustaron. Creían que el enemigo les pisaba los talones, que los perseguirían hasta el corazón mismo de los países del islam y hasta el fin del mundo..." (Amin Maalouf. León el africano. Madrid Alianza, 1988, p. 102).

Las relaciones entre la Casa ducal de Medina Sidonia y los Reyes Católicos aparecen como un parámetro esencial del capítulo de la ocupación de la ciudad de Melilla. Ocupada —que no conquistada: tierra de nadie en abandono- nueva diana de una oligarquía nobiliaria que competía con el mismo armiño regio, llevando a la otrora medieval Malila-Melilla a la identidad de una villa de señorío más de los Medina-Sidonia. El azar quiso que desde Sidón se llegara de nuevo a Tiro, como en los orígenes históricos de la colonización púnica del "Cabo Majestuoso". 
Dos artículos de este grupo inciden en la impronta del artista en una ciudad. Un arquitecto, mezcla de seny catalán y delirio gaudiano reprimido, Enric Nieto y Nieto, y un vidriero, el alemán Adolph Seiler. Este iluminó las vidrieras del Colegio del Cerro de Santiago, a modo de rosetón desperdigado en las paredes de naves varadas, fletadas por la burguesía bien de la ciudad, aliada de la baraka divina. Un legado de luz y color, hermoso y geométrico. El arquitecto, como un numen mediteráneo, trazó las nuevas cuevas de este ciudad habitada por Marte —el dios de la guerra- y nos lego la sede de Apolo en una leyenda historiada que nos narra un historiador del arte. Una nueva vertiente de Enrique Nieto que así se nos va haciendo cada vez más nítido y entrañable, abrazado al Modernismo emblemático de la Melilla extramuros.

Un estudio sobre el papel de la mujer en la Guerra Civil Española, nos aproxima a una visión desconocida de la ciudad. Si la Guerra Civil en Melilla ha sido hasta hoy un tema prácticamente tabú, no digamos nada de la consideración del papel de las mujeres en esa guerra y en todas las guerras. El artículo no puede obviar la ternura con toques de amargura difuminados por el tiempo- en un estilo directo y sencillo, que no evita el realismo descarnado, ni la descripción de visiones atroces.

$\mathrm{El}$ africanismo español es tratado en notas de un socíblogo, que disecciona en razones profundas de un fenómeno crucial en la "historia" moderna y contemporánea de España. Junto a ello, unas notas más sobre la comunidad judía de Melilla, en un aspecto tan importante como el de la ritualidad, explica pautas de comportamiento, actuales, que diseñan la realidad vital de Melilla.

El segundo bloque está dedicado - en planteamiento Monográfico- a la conmemoración de la "Campaña del Rif" (1909), al cumplirse ochenta años de su inicio. No pretende ser la celebración de una efemérides, hoy sólo recordada en la historia pasada. Al contrario pretende aclarar y divulgar un acontecimiento importante en el devenir de la historia mellillense. Para ello aparece un album gráfico de Melilla en 1909 y una excelente bibliograffa selecta y crítica que es esclarecedora. No nos interese resaltar las "virtudes" de la guerra y quisiéramos ser siempre historiadores de la paz. Pero, posiblemente ocultar los temas o tergiversarlos no es función del historiador comprometido con su época y con el fenómeno integrador de civilizaciones que prepara el advenimiento del siglo XXI.

La aportación fotográfica a este bloque monográfico se convierte más que nunca en testimonio documental: a modo de pintor de cámara que refleja en sus expertos ojos -imposibilitados de cerrarse por la estridencia de los hechos- las vicisitudes surgidas.

Los pueblos que no conocen su historia están abocados a repetirla, a veces en un cauce angustioso como la cancioncilla que evoca:

"En el Barranco del Lobo

Hay un fuente que mana

sangre de los españoles

derramada por su Patria". 
Cabe preguntarse que Patria es esa que derrama la sangre de sus hijos, para contestar que, a veces, la Patria viene representada por intereses mercantiles que deforman la realidad más consistente:

"Melilla ya no es Melilla

que es un matadero de hombres

por defender las minas

del Conde de Romanones".

El tercero de los bloques en que se estructura ALDABA, se dedica a Reseñas Bibliograficas. Se han reseñado cuatro obras de las editadas recientemente, aunque podríamos haber recogido otras. Pero todas las cosechas son estacionales y, quizás, estos eran los frutos maduros de la época, que no los mejores y más sabrosos.

En definitiva, vislumbra esta ALDABA un afán por mostrar aspectos poco conocidos de la historia de la ciudad. Como escribe Angel Ballesteros -inspirado tal vez en Braudel- "la historia confirma el papel tradicional y preponderante del Mare Nostrum, cruce de culturas y síntesis de civilizaciones". (Angel Ballesteros. Estudo diplomático sobre Ceuta y Melilla. Córdoba [Argentina]: El autor, 1989, p. 212)

Este Mar Meditrerráneo -el Mar de los "Aromis" - ha caracterizado largos periodos de nuestra historia, aunque a veces las arenas cegadoras del desierto -que Marmol tildó de espantoso, en pleno Garet cuajado de alimañas- propiciaron derroteros más continentales. De ahí que, en ocasiones, Melilla sea una ciudad indescriptible: "La ciudad no respondía a ninguna idea que Lena pudiera haberse hecho de antemano, y ello resultaba desde luego fascinante pero también amenazador...". (Miguel Bayon. Plaza de soberanía. Madrid: Mondadori, 1989, p. 21).

Una de las mil visiones de esta ciudad querida-odiada, pero nunca indiferente. Es lo que pretendemos con estas ALDABAS, a veces modernistas, a veces de sillares pétreos, a veces arqueológicas, a veces nítidas como vitrales, a veces lúcidas y otras no tanto: alterar la indiferencia y afectar una relación de interés por la historia de Melilla. Quizás ello ayude a sobrellevar -e incluso vencer-el síndrome melillense de inestabilidad, quizá recogido de los cientos de levas llegadas a la ciudad, como sillares humanos, durante casi cinco siglos. Como escribe Robert Saladrigas, evocando su servicio militar en Melilla: "Me sentfa encajonado en aquella ciudad pequeña y obsesivamente militarizada...Escribía poco. Me aburría. Y el aburrimiento, la monotonía de los días iguales a sí mismos, creaban en mi una laxitud paralizadora que frecuentemente se traducía en accesos de impaciencia. Vivía la inestabilidad característica de la recta final...Lefa con enfermiza voracidad aunque apenas hubiese nada medianamente bueno que leer". (Robert Saladrigas. Las imágenes de mi espejo. Madrid:Mondadori, 1988, p. 54)

Medianamente bueno que leer...Amen

\section{VICENTE MOGA ROMERO}

Coordinador de ALDABA, números monográficos sobre la Historia de Melilla 